\title{
Sectorization of environmental risk and human consumption of manganese in groundwater extracted from the Sinaloa River Aquifer
}

\author{
M. Norzagaray Campos ${ }^{1}$, M. Ladrón de Guevara Torres ${ }^{1}$, \\ E. Troyo Diéguez ${ }^{2}$, P. Muñoz Sevilla ${ }^{3}$, O. Llanes Cárdenas \\ \& H. A. González Ocampo ${ }^{1}$ \\ ${ }^{1}$ Centro de Investigación Interdisciplinaria para el Desarrollo Integral \\ Regional, IPN, Unidad Sinaloa, Mexico \\ ${ }^{2}$ Centro de Investigaciones Biológicas del Noroeste, SC, Mexico \\ ${ }^{3}$ Centro Interdisciplinario de Investigaciones y Estudios sobre Medio \\ Ambiente y Desarrollo (CIIEMAD), Mexico
}

\begin{abstract}
The research reported in this paper had three objectives. The first was to draw a map of the piezometric contours of the Sinaloa River Basin to enable an interpretation of the hydrodynamic behavior of the basin. The second objective was to establish a relationship between the hydrodynamics of the basin and levels of concentration of manganese (Mn), an element which is vital for human survival but toxic at high levels. Given that some of the rural and urban inhabitants of the basin consume untreated groundwater, the third objective was to create a map of the region showing the locations of high manganese level risk in the water. To characterize the hydrodynamics, 40 wells were selected at random. Groundwater depth, ground elevation, hydraulic load and piezometric surface were measured. A water sample was taken from each selected well, and spectrometric laboratory techniques employed to measure manganese and iron levels; the latter as a check on the robustness of Mn measurements on untreated water. The piezometric analysis showed the presence of a regional water source and a local water source, which has protected the basin from saline intrusion for many years. However there are sources of high manganese concentrations in a range of 0.01 to $1.2 \mathrm{mg} \mathrm{L}^{-1}$, which are moving with these two flows at average receptive velocities of $4.2 \times 10^{-3} \mathrm{mh}^{-1}$ and $1.6 \times 10^{-3} \mathrm{mh}^{-1}$. In an analysis of
\end{abstract}


groundwater samples, 22 (55\%) of the samples exceeded the EPA standard for commercial bottled drinking water and 12 (30\%) exceeded the Mexican NOM127-SSA1-1994-2000 standard for water for human use and consumption. The risk level was very high in two samples (5\%), high in 4 (10\%), moderately high in 3 (7.5\%), intermediate in 9 (22.5\%), low in 2 (5\%), and zero in $16(40 \%)$. This information can be used for numeric models of Mn transport and flow useful for safeguarding human health and for provision of sustainable management strategies in one of the largest aquifers in northwest Mexico.

Keywords: manganese, iron, groundwater, risk, human consumption, flow.

\section{Introduction}

Manganese (Mn) is one of most abundant metals occurring in nature (Jiménez [1]). It shares some properties with iron (Fe) and chromium (Cr). Dissolved $\mathrm{Mn}$ is found in subsoil waters in solid compounds of small particles, which, combined with oxygen $\left(\mathrm{O}_{2}\right)$, sulphur $(\mathrm{S})$ and chlorides $\left(\mathrm{Cl}^{-1}\right)$, do not evaporate, degrade or disappear. In underground porous media, Mn tends to accumulate, to adhere, and to be deposited, and levels of concentration tend to vary according to the rate of dispersion (Bianchini [2]). Higher concentrations are generally associated with underground water, in which levels of up to $2.5 \mathrm{mg} \mathrm{L}^{-1}$ have been recorded. For such water to be made suitable for use, various treatments are required. Large areas of land may have water with naturally high levels of manganese; if this water is extracted and used without any treatment, it may be toxic to the eosystem or agro-ecosystem (Castro [3]). Effects of using this water can include obesity, glucose intolerance, blood clots, skin problems, low cholesterol levels, skeletal disorders, changes in hair colour, or neurological effects (Manahan [4]). When this water is used for development, untreated water is ingested for prolonged periods, it tends to be a severe health hazard (Freed et al. [5]). Because of this, the issue of allowable Mn levels in water has been considered a high priority since 1980, when it was included in various documents and lists of standards (WHO [6]).

It has been difficult to establish accurate standards for allowable or recommendable $\mathrm{Mn}$ limits, as the effects depend on various factors and conditions, as well as the predominant type of organism or ecosystem in a given area or geographic region. The reactions of different organisms to the effects of Mn may vary. Small amounts of Mn are necessary for agriculture and drinking water. It is necessary to know the daily rate of intake per person, given the uncertainty of the risk and the need to prevent potential harmful effects. Since some urban and rural residents of the Sinaloa River Basin use untreated water for drinking, in order to ensure their health, it was considered important to determine the hydrodynamics of the basin and to find Mn concentration levels in the water in order to model the underground flow $(\phi)$ in the region by sector. 


\section{Methodology}

The Sinaloa River Basin (SRB) is a coastal plain with unconsolidated sedimentary igneous deposits caused by erosion and weathering of the Sierra Madre Occidental mountain range. The Mexican Statistical Institute (INEGI) [7], situates it in the RH10-SINALOA hydrological region, and Ávila [8] in hydrological region III. The climate is wet-and-dry (Ar-Aw) and there are four main natural tributaries; the Sinaloa River, the Arroyo De Cabrera, De Ocoroní and San Rafael and one artificial tributary built in the late 1940s, the Valle del Fuerte Canal (Norzagaray [9]). The basin is bordered on the north by the foothills of the Sierra Madre Occidental and on the west by the Gulf of California. The population of the basin is 270,260, and the largest concentrations of population are in the cities Guasave, Batamote, Tamazula and Sinaloa de Leyva (Figure 1).

To fulfill the first research objective of mapping the isopiezic contours of the basin, 40 wells were randomly selected in April 2008 from the universe of all main wells and boreholes utilized for drinking water and domestic use. Positions were taken with a 12-channel Garmin Olathe portable GPS. Elevations above sea level (masl) were measured using an Apex model ET-5 electronic theodolite employing the interpolation method. Soundings of the groundwater level (Nf) were taken monthly for three-day periods using an instantaneous piezometer. A 1978 study by the Técnicas Modernas de Ingenería company states that the SRB aquifer is unconfined; thus it can be assumed that hydraulic load $(\mathrm{H})$ in wells and/or boreholes coincides with Nf levels above sea level. Accordingly, following (Frenegal et al. [10]), H was calculated by subtracting $\mathrm{Nf}$ from h for each well and/or borehole. The isopiezic map was obtained by interpolating $\mathrm{H}$ using the SURFER 8.0 program (Emery [11]) to obtain the piezometric surfaces. This defines $\phi$, as it is perpendicular to the izopiezic contours (Hiscock [12]). Physical properties of the porous medium as previously described by Norzagaray et al. [9] were interpolated in SURFER 8.0 under the same dimensions of $\mathrm{H}$. Both parameters were then fed into the FlowPATH 6.0 program, and Darcy's Law was used to calculate average $\phi$ velocity (Fetter [13]). To meet the second study objective, a water sample was taken from each well or borehole. The samples were labeled, prepared and sent to the laboratory for analysis. In the laboratory, the samples were filtered and aliquots were taken. The $\mathrm{pH}$ was adjusted according to which element was to be analyzed. The samples were stored in plastic bottles at $4^{\circ} \mathrm{C}$ until the respective analysis was carried out. Mn and Fe concentrations were analyzed in triplicate by two methods; (a) filtration colorimetry (Silva et al. [14]) and ultraviolet spectrometry, cited by the Association of Official Analytical Chemists (AOAC) [15].

For analysis of drinking water by $\mathrm{Mn}$ concentration, two references were used; the EPA standard of $0.05 \mathrm{mg} \mathrm{L}^{-1}$ for bottled drinking water (ATSDR [16]), and $0.15 \mathrm{mg} \mathrm{L}^{-1}$, the allowable limit set by the NOM-127-SSA1-1994-2000 Mexican standard for human use and consumption of water in general (DOF [17]). Because Fe is associated with $\mathrm{Mn}$ in groundwater, Fe was also measured, as a reference to validate the presence of $\mathrm{Mn}$ in the samples (Jiménez [1]). The 


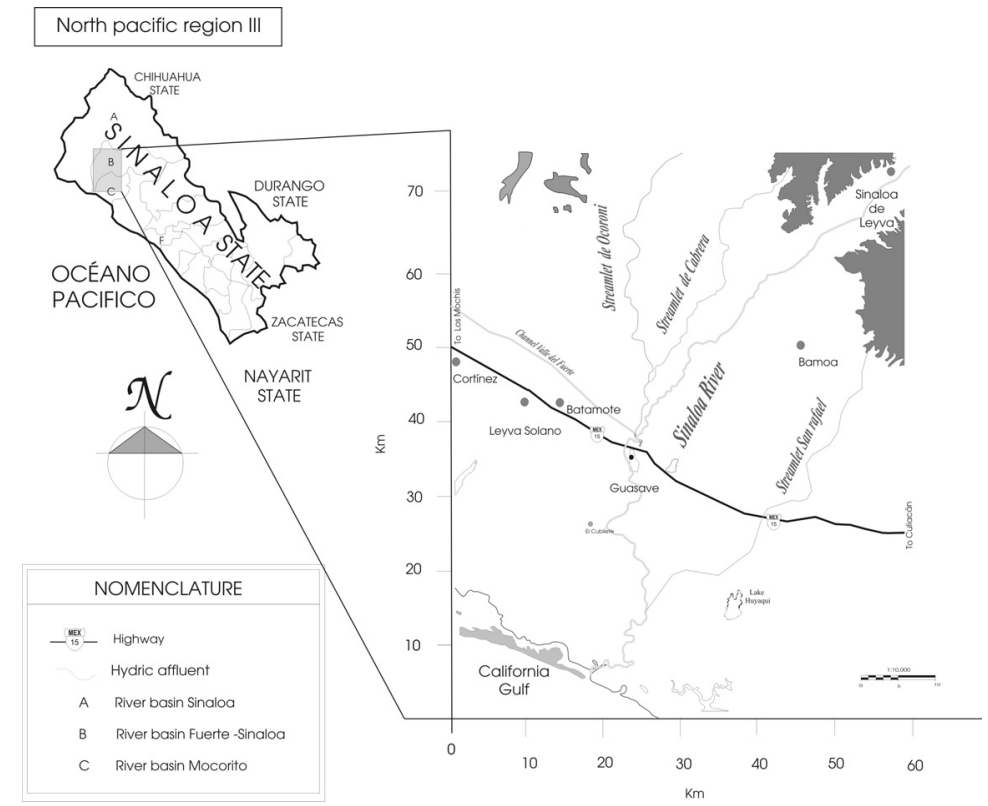

Figure 1: Location of the North Pacific III Hydraulic Region and the Guasave Valley, Sinaloa de Leyva.

limit of $0.3 \mathrm{mg} \mathrm{L}^{-1}$, as specified in the amended NOM-127-SSA1-1994-2000 standard (DOF [17]), was used. The map was prepared using the measured Mn and Fe concentration values, with intermediate values interpolated using SURFER 8.0. Once the hydrodynamics, $\phi$ velocity, and Mn concentration levels had been established, the map of Mn concentrations was layered on the map of the urban layout of the region, in order to divide it into sectors and map probable Mn dispersion (the third study objective). The $\phi$ gradients were mapped under the assumption that an intersection of two or more $\phi$ indicated a convergent gradient, and expansion or loss (drift) of $\phi$ indicated divergence (Hiscock [12]). To transfer the results to a risk map based on the $0.15 \mathrm{mg} \mathrm{L}^{-1} \mathrm{Mn}$ standard, risk was divided into seven levels and the drinking water hazard of each level classified. The levels were: 6: Very high (Ma), 5: High (A), 4: Moderately high (Md), 3: Intermediate (I), 2: Low (B) and 1: No risk (N).

\section{Results and discussions}

$\mathrm{H}$ varied from 0.6 to 51.8 meters, with an average of 25.5 masl. Values of $\mathrm{H}$ are shown in Table 1; the piezometric map is shown in Figure 2, Section A. The piezometric lines are parallel to the coast and follow similar contours to the topography. The equipotential contours appear perpendicular, and two types of $\phi$ can be observed (Tóth [18]); a main or regional flow from the northwest 
(Figure 2, Part B) and an intermediate flow that enters the basin at the foothills of the mountain range in the southeast (Figure 2, Part C). The average of the regional $\phi$ velocity as calculated by FLOWpath 6.0 was $4.2 \times 10^{-3} \mathrm{mh}^{-1}$ and of the intermediate $\phi$ velocity, $1.6 \times 10^{-3} \mathrm{mh}^{-1}$. The northwest current enters the piezometric surface at 44 masl, and in the course of its flow $\mathrm{H}$ drops from 20 to 12 masl. It is fed by the Valle del Fuerte Canal, and its final destination is the Gulf of California. As shown in Figure 2, a major portion of the volume of the northwest current is consistent with that reported by Toutcha et al. [19]; of the total volume, $3473.73 \mathrm{Mm}^{3}$ converges to the RH10-SINALOA in the state of Chihuahua. The southwest current similarly flows from a piezometric surface of 44 masl, fed from the Sinaloa River. Both currents have, over a long period of time, prevented the intrusion of salt into the basin (TMISA [20]).

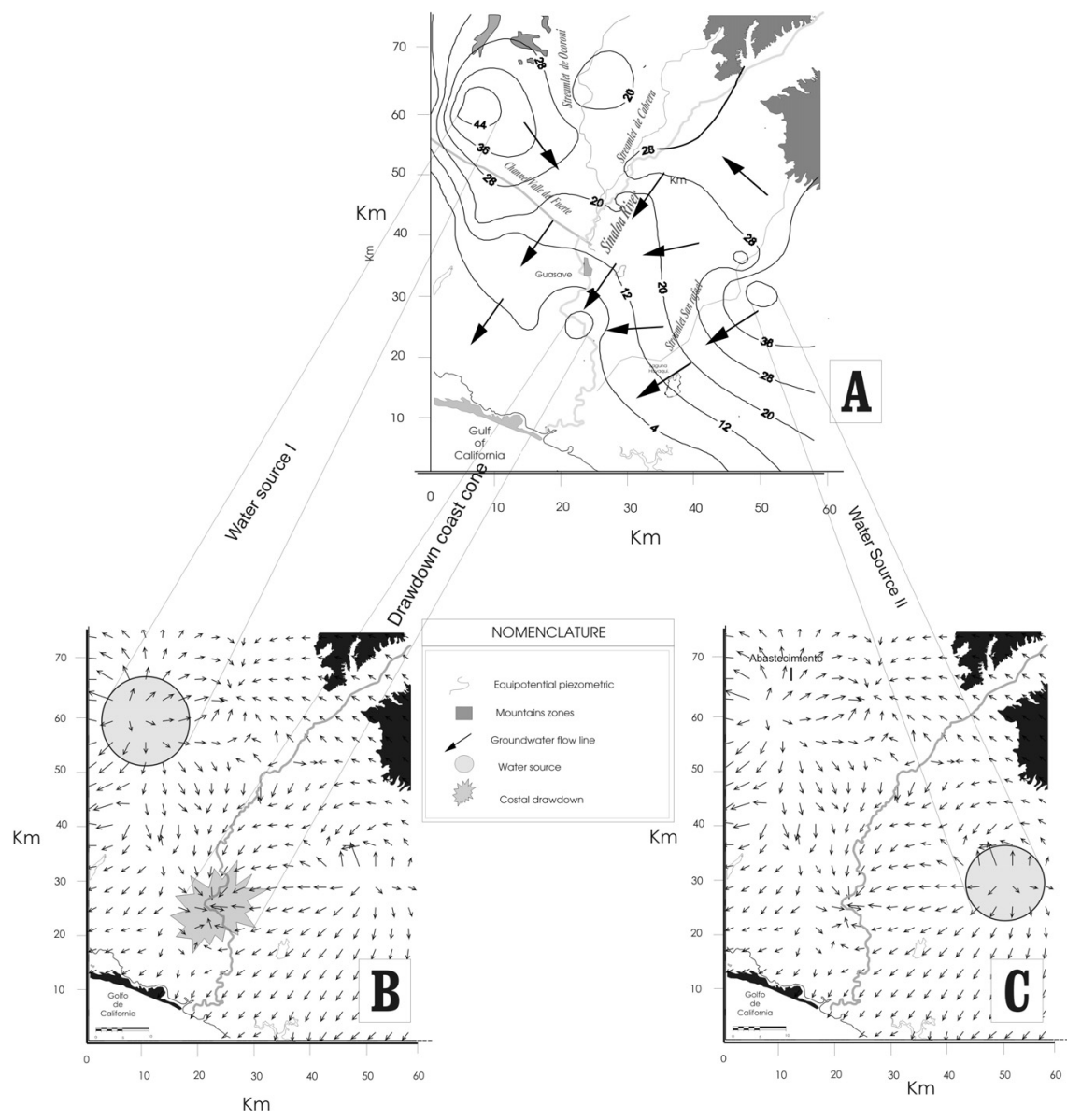

Figure 2: $\quad$ Piezometric levels, lines of flow, sources of supply and areas of groundwater depletion. 


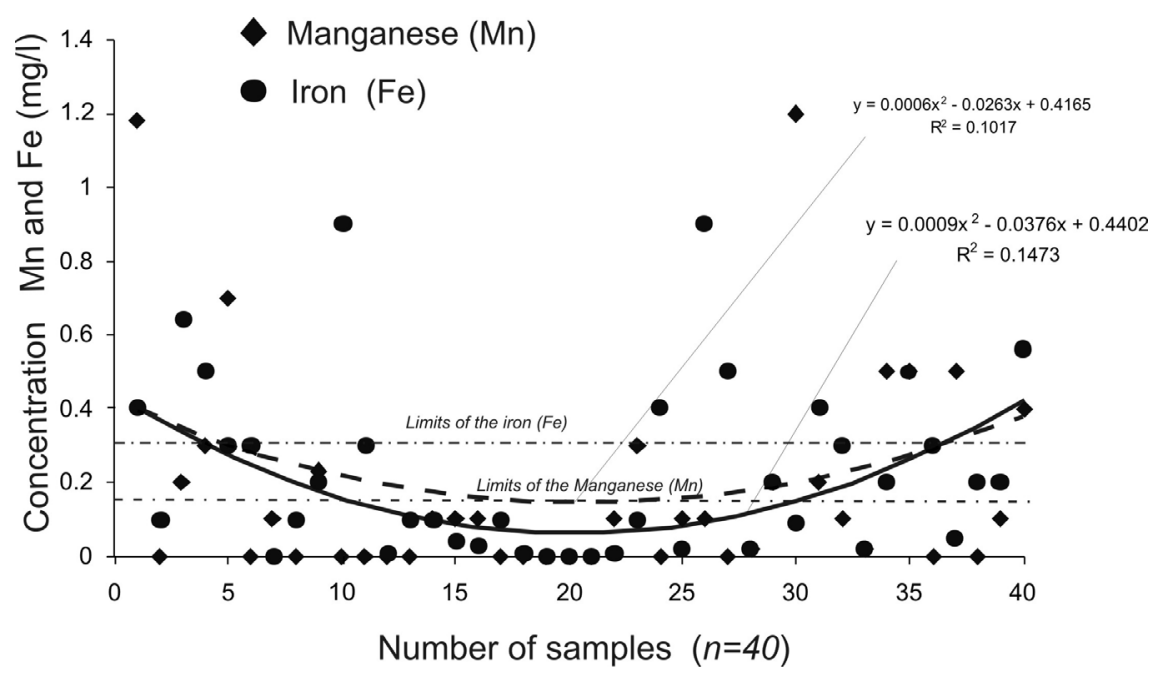

Figure 3: Distribution of manganese and iron concentrations in groundwater samples from the Sinaloa River Basin.

The distribution of $\mathrm{Mn}$ and Fe concentrations in the groundwater samples analyzed is shown in Figure 3. A nonlinear trend, possibly due to variability resulting from the interactions between the flows, can be observed.

Although the $\phi$ direction has long mitigated the effects of seawater intrusion, apparently in 2008 a 0.06 masl cone of depression appeared, which was due to demand caused by intensive farming, which considerably exceeded the natural recharge (Figure 4, Section A). This runaway demand is attributed mostly to agriculture; in 1967 demand was $430 \mathrm{~mm}^{3} /$ year compared to a $230 \mathrm{~mm}^{3} /$ year recharge; in $1968130 \mathrm{~mm}^{3}$ /year compared to a $200 \mathrm{~mm}^{3} /$ year recharge, and in 1977 the volume of water extracted was $500 \mathrm{~mm}^{3} /$ year (TMISA [20]). Moreover it has recently become known that $1131.03 \mathrm{Mm}^{3} /$ year has already been promised to the productive sector (SEMARNAT [21]). This is well above the $510.46 \mathrm{Mm}^{3}$ /year annual recharge in the Northern Sinaloa State Planning Subregion (PEDUES) [22], of which the aquifer only provides 200$300 \mathrm{Mm}^{3} /$ year.

Table 1 also shows Mn and Fe concentration levels for the 40 water samples. According to the quality standards used in this study, the concentration of $\mathrm{Mn}$ in the 40 samples analyzed was in the range of 0 to $1.2 \mathrm{mg} \mathrm{L}^{-1}$ and Fe between 0 and $0.9 \mathrm{mg} \mathrm{L}^{-1}$.

Twenty-two samples (55\%) had levels above the EPA bottled drinking water standard of $0.05 \mathrm{mg} \mathrm{L} \mathrm{L}^{-1}$ and therefore were not suitable for consumption directly from the well or borehole (Table 1). As Table 1 also shows, 12 samples (30\%) had Mn levels above the NOM-127-SSA1-1994-2000 standard of 0.15 $\mathrm{mg} \mathrm{L}^{-1}$, and 15 samples (37.5\%) showed Fe levels above $0.3 \mathrm{mg} \mathrm{L}^{-1}$ (Figure 3). If both standards are applied, Mn levels exceeded the standards; the water is unfit for human consumption and would require physical and/or chemical treatment to remove the excess $\mathrm{Mn}$ and Fe (Figure 3). 


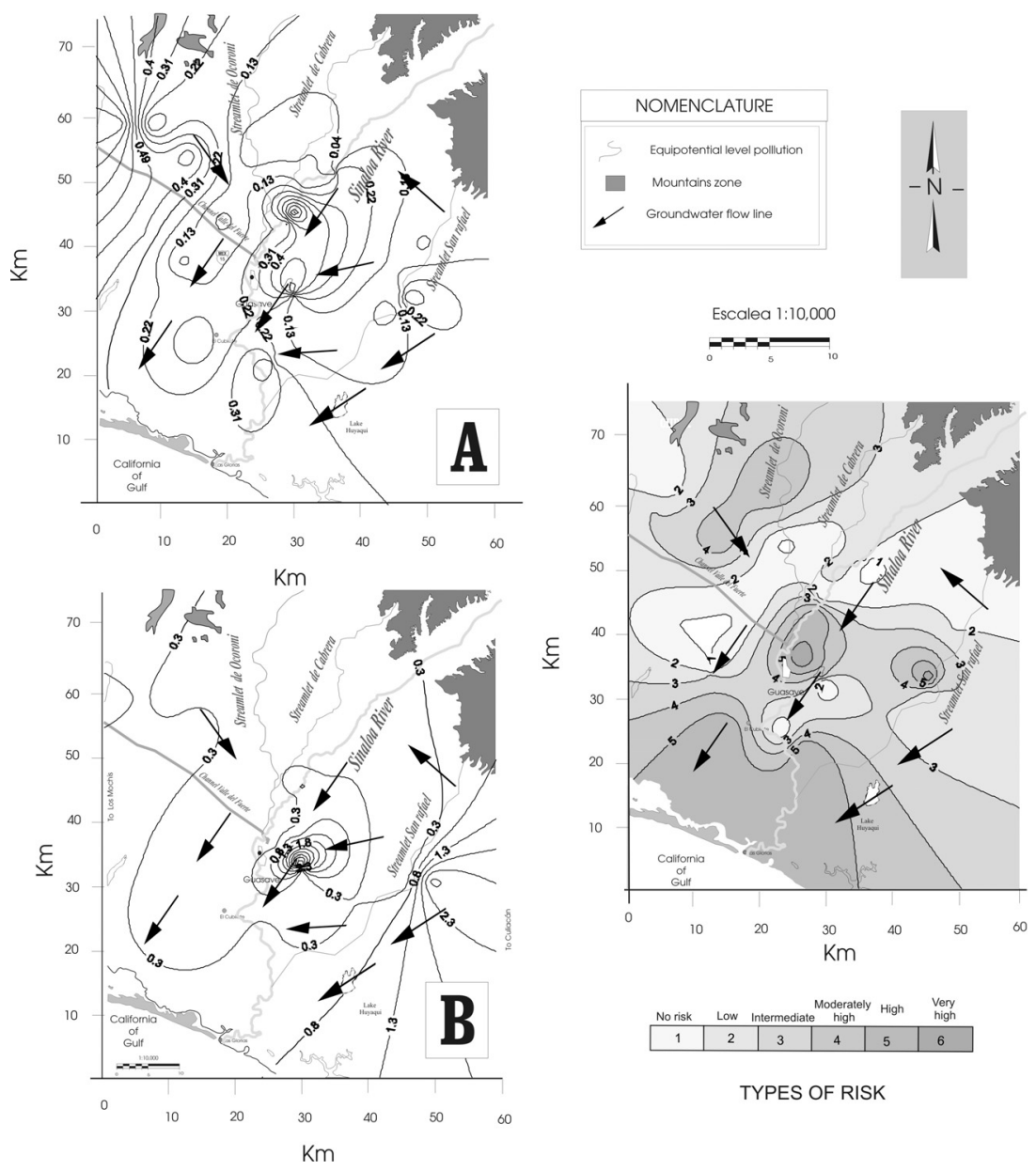

Figure 4: Spatial variation in the direction of groundwater flow and distribution of concentration levels (mg/l) of manganese (A), iron (B) and risk map for manganese intake (C) in the Sinaloa River Basin.

Populations with $\mathrm{Mn}$ and Fe concentrations that are high according to the NOM-127-SSA1-1994-2000 standard are listed in Table 2 in descending order of risk. Sections A, B and C of Table 4 show Mn and Fe concentration levels from Tables 1 and 2 and the associated risk classifications proposed in this study with respect to the direction of $\phi$. It can be observed that $\mathrm{Mn}$ and Fe concentrations show geometric behavior, with similar coverage areas.

In the northern part of the basin, levels of Mn concentration were similar to Fe concentrations, and were higher than levels specified in the standards. At a distance of $9 \mathrm{~km}$ from the coastal cone of depression, Fe was present in the 
Table 1: Magnitude of piezometric levels and manganese and iron concentrations ( $\left.\mathrm{mg} \mathrm{L}^{-1}\right)$.

\begin{tabular}{|c|c|c|c|c|c|c|c|c|c|c|c|c|c|}
\hline $\begin{array}{c}\text { Number } \\
\text { sample }\end{array}$ & $\begin{array}{c}\text { Piezometric Head } \\
\text { H } \\
\text { masl* }\end{array}$ & $\begin{array}{c}\text { Manganese } \\
\mathrm{Mg} \\
\mathrm{mg} / 1\end{array}$ & $\begin{array}{c}\text { sSa-1994 } \\
0.15 \mathrm{mg} / \mathrm{l}\end{array}$ & $\begin{array}{c}\text { EPA } \\
0.05 \mathrm{mg} / 1\end{array}$ & $\begin{array}{l}\text { Iron } \\
\mathrm{Fe} \\
\mathrm{Mg} / \mathrm{l}\end{array}$ & $\begin{array}{l}\text { SSAl-1994 } \\
0.3 \mathrm{mg} / \mathrm{l}\end{array}$ & $\begin{array}{c}\text { Number } \\
\text { Sample }\end{array}$ & $\begin{array}{c}\mid \begin{array}{c}\text { Piezomtric Head } \\
H \\
\text { mas }\end{array} \\
\left.\right|^{*}\end{array}$ & $\begin{array}{c}\text { Manganese } \\
\mathrm{Mg} \\
\mathrm{mg} / \mathrm{l}\end{array}$ & $\begin{array}{c}\text { ssat-1994 } \\
0.15 \mathrm{mg} / \mathrm{I}\end{array}$ & $\begin{array}{c}\text { EPA } \\
0.05 \mathrm{mg} / \mathrm{l}\end{array}$ & $\begin{array}{c}\text { Iron } \\
\mathrm{Fe} \\
\mathrm{mg} / \mathrm{l}\end{array}$ & $\begin{array}{l}\text { SSA1-1994 } \\
0.3 \mathrm{mg} / 1\end{array}$ \\
\hline 1 & 14.9 & 1.18 & $\bar{x}$ & $x$ & 0.4 & $\bar{x}$ & 21 & 29.8 & 0 & & & 0 & \\
\hline 2 & 15.8 & 0 & & & 0.1 & & 22 & 31.0 & 0.1 & & $x$ & 0.01 & \\
\hline 3 & 14.9 & 0.2 & $x$ & $x$ & 6.4 & $x$ & 23 & 18.4 & 0.3 & $x$ & $x$ & 0.1 & \\
\hline 4 & 19.0 & 0.3 & $x$ & $x$ & 0.5 & $x$ & 24 & 24.1 & 0 & & & 0.4 & $x$ \\
\hline 5 & 21.2 & 0.7 & $x$ & $x$ & 0.3 & $x$ & 25 & 47.4 & 0.1 & & $x$ & 0.02 & \\
\hline 6 & 25.9 & 0 & & & 0.3 & $x$ & 26 & 46.3 & 0.1 & & $x$ & 0.9 & $x$ \\
\hline 7 & 37.1 & 0.1 & & $x$ & 0 & & 27 & 49.4 & 0 & & & 0.5 & $x$ \\
\hline 8 & 32.5 & 0 & & & 0.1 & & 28 & 37.8 & 0.02 & & & 0.02 & \\
\hline 9 & 22.7 & 0.23 & $x$ & $x$ & 0.2 & & 29 & 23.1 & 0.2 & $x$ & $x$ & 0.2 & \\
\hline 10 & 21.0 & 0 & & & 0.9 & $x$ & 30 & 38.0 & 1.2 & & $x$ & 0.09 & \\
\hline 11 & 35.7 & 0 & & & 0.3 & $x$ & 31 & 37.1 & 0.2 & $x$ & $x$ & 0.4 & $\mathrm{x}$ \\
\hline 12 & 29.5 & 0 & & & 0.01 & & 32 & 51.8 & 0.1 & & $x$ & 3 & $x$ \\
\hline 13 & 32.0 & 0 & & & 0.1 & & 33 & 9.1 & 0.02 & & & 0.02 & \\
\hline 14 & 33.6 & 0.1 & & $x$ & 0.1 & & 34 & 9.1 & 0.5 & $x$ & $x$ & 0.2 & \\
\hline 15 & 32.6 & 0.1 & & $x$ & 0.04 & & 35 & 0.6 & 0.5 & $x$ & $\mathrm{x}$ & 0.5 & $x$ \\
\hline 16 & 29.6 & 0.1 & & $x$ & 0.03 & & 36 & 8.1 & 0 & & & 0.3 & $x$ \\
\hline 17 & 21.3 & 0 & & & 0.1 & & 37 & 13.5 & 0.5 & $x$ & $x$ & 0.05 & \\
\hline 18 & 11.1 & 0 & & & 0.01 & & 38 & 13.1 & 0 & & & 0.2 & \\
\hline 19 & 20.0 & 0 & & & 0 & & 39 & 40.5 & 0.1 & & $x$ & 0.2 & \\
\hline 20 & 30.9 & 0 & & & 0 & & 40 & 29.9 & 0.4 & $x$ & $x$ & 0.56 & $x$ \\
\hline
\end{tabular}

Table 2: Population and manganese concentration levels in descending order of risk of consumption of untreated water from wells and boreholes in the Sinaloa River Basin, using the classifications proposed in this study.

\begin{tabular}{|c|c|c|c|c|c|c|c|c|c|}
\hline $\begin{array}{l}\text { Number } \\
\text { Samples }\end{array}$ & Population & $\begin{array}{c}\text { Manganese } \\
\mathrm{Mg} \\
\mathrm{mg} / 1\end{array}$ & $\begin{array}{l}\text { Magnitude } \\
\text { of the } \\
\text { rank }\end{array}$ & $\begin{array}{l}\text { Type of the } \\
\text { rank }\end{array}$ & & Population & $\begin{array}{c}\text { Manganese } \\
\mathrm{Mg} \\
\mathrm{mg} / \mathrm{l}\end{array}$ & $\begin{array}{l}\text { Magnitude } \\
\text { of the } \\
\text { rank }\end{array}$ & $\begin{array}{l}\text { Type of the } \\
\text { rank }\end{array}$ \\
\hline 30 & Palmarito & $\overline{1.2}$ & 7 & $\overline{\mathrm{Ma}}$ & 32 & 15 de oct. & 0.1 & 3 & $T$ \\
\hline 1 & Guasave. & 1.18 & 7 & Ma & 39 & Mesquitón 2. & 0.1 & 3 & 1 \\
\hline 5 & Nio. & 0.7 & 6 & A & 28 & Reparo. & 0.02 & 2 & B \\
\hline 34 & Callejones Tamz & 0.5 & 6 & A & 33 & Tesitos. & 0.02 & 2 & B \\
\hline 35 & Tamazula. & 0.5 & 6 & A & 2 & Burrión N. & 0 & 1 & $\mathrm{~N}$ \\
\hline 37 & Buenavista. & 0.5 & 6 & A & 6 & Cruz Blanca. & 0 & 1 & $\mathrm{~N}$ \\
\hline 40 & M. Bernal. & 0.4 & 5 & Sa & 8 & Bamoa pozo. & 0 & 1 & $\mathrm{~N}$ \\
\hline 4 & R. Castro. & 0.3 & 5 & $\mathrm{Sa}$ & 10 & Lichis. & 0 & 1 & $\mathrm{~N}$ \\
\hline 23 & Estación Naranjd & 0.3 & 5 & $\mathrm{Sa}$ & 11 & Carboneras. & 0 & 1 & $\mathrm{~N}$ \\
\hline 9 & El varal. & 0.23 & 5 & $\mathrm{Sa}$ & 12 & Port de Gálve & 0 & 1 & $\mathrm{~N}$ \\
\hline 3 & Burrión P. & 0.2 & 4 & la & 13 & P. Gálves Nol & 0 & 1 & $\mathrm{~N}$ \\
\hline 29 & Serranito. & 0.2 & 4 & la & 17 & Utatabe. & 0 & 1 & $\mathrm{~N}$ \\
\hline 31 & Entre 26 y 29. & 0.2 & 4 & la & 18 & La entrada. & 0 & 1 & $\mathrm{~N}$ \\
\hline 7 & Bamoa Llave. & 0.1 & 3 & I & 19 & Nacho Bojórq & 0 & 1 & $\mathrm{~N}$ \\
\hline 14 & El Sabino. & 0.1 & 3 & 1 & 20 & La Trinidad. & 0 & 1 & $\mathrm{~N}$ \\
\hline 15 & Carboneras. & 0.1 & 3 & 1 & 21 & Toruño. & 0 & 1 & $\mathrm{~N}$ \\
\hline 16 & León Fonseca. & 0.1 & 3 & 1 & 24 & Sta. Fe. & 0 & 1 & $\mathrm{~N}$ \\
\hline 22 & El Palotal. & 0.1 & 3 & i & 27 & Fco. Villa. & 0 & 1 & $\mathrm{~N}$ \\
\hline 25 & La pitaya. & 0.1 & 3 & 1 & 36 & Retiro. & 0 & 1 & $\mathrm{~N}$ \\
\hline 26 & El Coyote. & 0.1 & 3 & I & 38 & Mesquitón. & 0 & 1 & $\mathrm{~N}$ \\
\hline
\end{tabular}

central zone with a source of high concentrations, covering an area of approximately $80 \mathrm{~km}^{2}$. The source was intersected by one of the flows parallel to the Sinaloa River and its volume increased toward the Gulf of California. The northwest $\phi$ transported Fe and showed dissolution processes dispersing the mineral in the basin in co-action with recharge in the central west portion near 
the Valle Fuerte Canal, carrying it to its final destination, namely the Gulf of California coast (Figure 4, Part B).

Water in the intermediate $\phi$ in the southwest exceeded both standards for $\mathrm{Mn}$ concentration. The northwest current showed the greatest concentration of $\mathrm{Mn}$, with a high concentration $\left(0.49 \mathrm{mg} \mathrm{L}^{-1}\right)$ at the source, which is dispersed in the basin, reaching the coast with a level of $0.22 \mathrm{mg} \mathrm{L}^{-1}$. It seems this behavior is explained by a natural decrease in concentration along the course of the flow. Since Mn in groundwater is not degraded nor does it disappear, it follows that the rest of the mineral, estimated at a concentration of $0.27 \mathrm{mg} \mathrm{L}^{-1}$, attaches to particles of the porous medium and/or is deposited in sedimentary strata in the basin (Bianchini [2]). At its source, the southwest current had a Mn concentration of $0.22 \mathrm{mg} \mathrm{L}^{-1}$, but where it joined the regional current near the cone of depression at a piezometric level of 4 masl, the concentration was $0.09 \mathrm{mg} \mathrm{L}^{-1}$. Another interesting feature of $\mathrm{Mn}$, similar to $\mathrm{Fe}$, was that there was a source of high concentration in the central area, covering approximately $180 \mathrm{~km}^{2}$. This source moved parallel to the Sinaloa River towards the cone of depression. Consequently, since the area around the cone of depression receives flows with different Mn concentrations, the mineral accumulates so that over time the level reaches high concentrations in coastal areas; as much as $0.31 \mathrm{mg}$ $\mathrm{L}^{-1}$, which is much higher than the standards cited in this study. The risk was classified as very high in two samples (5\%), high in four (10\%), moderately high in three $(7.5 \%)$, intermediate in nine $(22.5 \%)$, low in two $(5 \%)$, and zero in 16 samples (40\%) (Figure 4, Section C).

\section{Conclusions}

Areas where both of the standards for $\mathrm{Mn}$ and Fe concentrations were exceeded may be influenced by environmental conditions at the time of year when sampling was done; in this study 55\% of samples exceeded the EPA Mn standard and 30\% exceeded the NOM-127-SSA1-1994-2000 standard but the result could have varied according to whether water was sampled in the rainy season or the dry season. Therefore the average of the 40 samples in the present study is only evidence of one particular scenario, although the questionable quality of the groundwater in the Sinaloa River Basin was noticeable. Because of this, it is recommended that further measurements of the selected parameters be made to identify the range of the sources of high concentrations as reported in Sections A and $\mathrm{B}$ in Figure 4 more precisely, and to make more specific decisions and corrective action for each case. The high concentrations of $\mathrm{Mn}$ in underground water were attributed to the lack of $\mathrm{O}_{2}$; the $\mathrm{Mn}$ can therefore not oxygenate, or precipitate or disappear. As stated by Bianchini [2], it follows that it adheres to particles in the ground and is then deposited in sediments in the basin. With respect to sources of high concentration in Section A of Figure 4, it is recommended that further detailed research be conducted to identify and evaluate the processes of $\mathrm{Mn}$ deposition and adhesion to porous media, as these areas could be a source of risk for human consumption, especially if Mn accumulates in the ground. When these areas are properly characterized, more effective 
processes can be used to remedy the situation. As the matter stands, given that there are still urban areas lacking water supply and sewage networks, it is suggested that methods be applied to eliminate or significantly decrease Mn and Fe concentration where untreated water is used for human consumption in centers where the concentrations do not meet the quality standards for direct human consumption. Such treatments could include chemical precipitation, $\mathrm{pH}$ adjustment, aeration, or ionic exchange. When variations in space and time are analyzed (concentrations might be higher in the dry season than in the rainy season, as the minerals might be dissolved and carried away into the porous medium more in the latter than the former), since this study was conducted during the dry season, it is recommended to also conduct systematic sampling and analysis during the rainy season in order to observe and throw more light on transport processes and identify sites towards which the sources of high concentration could be directed. This would increase information about the areas of risk in Section C of Figure 4. There is no doubt that drinking water must contain Mn. However, despite the benefits it provides, such as aiding rapid growth, nutrition, increasing the body's antioxidant abilities and slowing down anti-inflammatory effects of the damage from continuous exposure that could adversely affect health, such as irreversible damage to brain cells (Freed et al. [5]), allowable limits should be added to the World Health Organization Guidelines for Quality (WHO [6]).

\section{References}

[1] Jiménez, S.B. 2001. La contaminación ambiental en México. La contaminación ambiental en México: Causas, efectos y tecnología apropiada. Editorial Limusa. Mexico. 928 pp.

[2] Bianchini, F. 2007. Contaminación de agua en el área de explotación minera del proyecto San Martin, en el Valle de Siria y repercusiones sobre la salud humana. Technical Report. 9 p.

[3] Castro, M.E. 1992. El Hierro y el Manganeso en la salud Humana. Asociación Nacional de Empresas e Instituciones de Servicio de Agua Potable y Alcantarillado (Eds). Technical Report. 6 p.

[4] Manahan, S.E. 2004. Environmental Chemistry. CRC Press, USA. 811 p.

[5] Freed, C.R., Breeze, R.E., Schneck, S.A. 1995. Transplantation of fetal mesencephalic tissue in Parkinson's disease. New England Journal of Medicine. 333: 730-731.

[6] World Health Organization (WHO). 1996. Guidelines for Drinking Water Quality, (Second Edition) vol. 2. Health Criteria and Other Supporting Information. Geneva, Switzerland.

[7] INEGI (Instituto Nacional de Estadísticas Geografía e Informática). 2005. Anuario Estadístico del Estado de Sinaloa. Gobierno del Estado de Sinaloa, Mexico. 321 p.

[8] Ávila, P.G. 2002. Cambio Global y Recursos Hídricos en México: Hidropolítica y Conflictos. Instituto Nacional de Ecología, Mexico. 107 p. 
[9] Norzagaray, C.M., Herrera, B.J., Ladrón, G.T.M. 2004. Variación espacial de la conductividad hidráulica para suelos del acuífero costero de Guasave, Sinaloa. Revista Tláloc, Asociación Mexicana de Hidráulica. 30(1): 11-16.

[10] Frenegal, M., Lopez, G.J. \& Chivelet, J.M. (2000). Diccionario de ciencias de la tierra. Complutense (Eds.). España, 879 pp.

[11] Emery, X. 2007. Conditioning simulations of Gaussian random fields by ordinary kriging. Mathematical Geology. 39(6): 607-623.

[12] Hiscock, H. 2005. Hydrogeology. Principles and Practice. Blackwell, 389 p.

[13] Fetter, C.W. 2001. Upper Saddle River, New Jersey. Applied Hydrogeology, Prentice-Hall Inc. USA. 598 pp.

[14] Silva A.A., Castro S.S., Medina G.P. 1996. Manual de procedimientos analíticos para aguas y efluentes. Ministerio de Vivienda, Ordenamiento Territorial y Medio Ambiente, Dirección Nacional de Medio Ambiente, España. 174 p.

[15] Association of Official Analytical Chemists (AOAC). 1984. Official Methods of Analysis (14th ed). Arlington, USA. 141 p.

[16] Agency for Toxic Substances and Disease Registry (ATSDR). 2000. Reseña Toxicológica de los Manganeso. Department of Health and Human Services, Atlanta, 8 p.

[17] Diario Oficial del la Federación (DOF). 1994-2000. NOM-127-SSA11994-2000; Norma Oficial Mexicana sobre Salud ambiental, agua para uso y consumo humano-límites permisibles de calidad y tratamiento que debe someterse al agua para su potabilización, México D.F.

[18] Tóth, J. 2000. Las aguas subterráneas como agente geológico, causas procesos y manifestaciones, Boletín Geológico y Minero. 111(4): 9-26 pp.

[19] Toutcha L., Sosa M., Soto R. 2005. La flora de las barrancas del Cobre, Chihuahua, México. Ecología Aplicada. 4(12):17-23 pp.

[20] Técnicas Modernas de Ingeniería (TMISA). 1978. Estudio de Evaluación de acuíferos en la zona Fuerte - Sinaloa, en el estado de Sinaloa. CONAGUA, Culiacán Sinaloa, México. 314 p.

[21] SEMARNAT. 2006. Secretaria de Medio Ambiente y Recursos Naturales (SEMARNAT) Diario Oficial (Primera Sección). Acuerdo que da a conocer el resultado de los estudios de disponibilidad media anual de las aguas superficiales en las cuencas hidrológicas del Río Sinaloa 1, Arroyo Ocoroni, Arroyo Cabrera y Río Sinaloa 2. México D.F. 24 de Noviembre.

[22] PEDUES. 2007. Plan Estatal de Desarrollo Urbano del estado de Sinaloa (PEDUES). Gobierno del estado-Secretaria de Desarrollo Social y Sustentable. Culiacán Sinaloa, Mexico. 133p. 